\title{
Arranging public support to unfold collaborative modes of governance in rural areas
}

ABSTRACT Raising collective agency is key to successful place-based development approaches. Existing policy arrangements have, however, been criticised, suggesting a need to effectuate more collaborative modes of governance. This paper shall contribute to a better understanding of how public support can best be arranged to raise collective agency for a more collaborative mode of governance in rural areas. The paper elaborates on findings of empirical investigations conducted within the EU FP7 project DERREG. It will be shown that differences in effectuating more collaborative modes of governance can partly be ascribed to different political dynamics, economic and demographic situations as well as the presence of a shared sense of place. To raise collective agency effectively requires a joint reconsideration and restructuring of the division of roles and tasks, including those of public administration. This can be supported by facilitating joint reflexivity among development actors and giving room for collaborative leadership and operational flexibility within policy arrangements.

Key words. Collective agency; collaborative leadership; institutional arrangements; operational interfaces; learning rural area; place-based development

\section{Introduction}

In the European Union, place-based approaches to rural development are increasingly favoured, because they aim to strengthen the resilience of rural areas against global pressures by decreasing state dependencies and increasing the economic competitiveness of rural areas (Amin, 2004; Barca, 2009; Bristow, 2010; Healey et al., 2003; Lowe et al., 1995; Marsden and Bristow, 2000; Murdoch, 2000; Nienaber, 2007; O'Brian, 2011; OECD, 2006; Ray, 2006; Reimer and Markey, 2008; Shucksmith, 2009; Taylor, 2012; Tomaney, 2010). Place-based 
development approaches require an increased self-efficacy of rural residents, which can be stimulated through bottom-up development and decentralisation of decision making processes (Amin, 2004; Böcher, 2008; Bruckmeier, 2000; Dargan and Shucksmith, 2008). In this process, various development actors need to develop joint visions and joint activities and create synergies (Collinge and Gibney, 2010; Gibney, 2011). Raising collective agency is thus key to place-based development (Amin, 2004; Collinge and Gibney, 2010; Gibney, 2011; Gieryn, 2000; Healey et al., 2003; Massey, 1991; Roep et al., 2009; Swanson, 2001).

Public policy can raise collective agency through supporting communication and dialogue, meaningful partnerships between local and extra-local practitioners, an ethos of social inclusion, and structures for democratic decision making (Collinge and Gibney, 2010; Swanson, 2001). In rural areas, however, supportive arrangements aimed at raising collective agency have received numerous criticisms with regard to their effectiveness and operationalization (see Amin, 2004; Cleaver, 2002; Lee et al., 2005; Ray, 2006; Shortall, 2008; Shortall and Shucksmith, 2001). High and Nemes (2007) argue that institutional arrangements such as LEADER may even suppress participation when implemented as a general recipe showing indifference to the particularities of place. Bruckmeier (2000), for example, contends that LEADER only benefits the elites with considerable agency, that is, with the knowledge and power to influence decision making in their favour, while failing to include marginalized groups. Shortall (2008) further argues that participation might introduce power imbalances and that targeted beneficiaries may choose not to participate as they do not see the benefits. Multi-level governance arrangements seemingly constructed to raise collective agency can thus mask realities about how power and authority remains with central government (Hadjimichalis and Hudson, 2006; Jessop, 1990; Jones, 2001). Place-based development approaches thus need more reflexive approaches to governance, replacing 
hierarchical, policy-centred leaderships with collaborative modes of governance and crossboundary leadership (Collinge and Gibney, 2010).

This paper shall contribute to a better understanding of how public support can best be arranged to raise collective agency for a more collaborative mode of governance in rural areas. The study should thereby extend the discussion of institutional reform in participatory and place-based development approaches (Healey, 2006b; Healey et al., 2003; Shucksmith, 2010). Public support is defined as public policies and programmes, funds, infrastructure and knowledge facilitation provided by European, national or subnational levels of public administration. The paper elaborates on the findings of comparative empirical investigations into supportive arrangements intending to raise collective agency in six European and highly diverse rural areas conducted within the EU FP7-funded project DERREG (Roep et al., 2011). In the following section, the research tool is introduced. This tool, referred to as the learning rural area framework, can be used to map, analyse and compare how public support is arranged to support interfaces through which various development actors learn to work together. Following the framing of the learning rural area, the six case study areas will be highlighted briefly, and the research method will be explained, particularly focusing on the use of the learning rural area framework as research tool. Afterwards, selected policy arrangements are described and compared. Differences in modes of governance across the case study areas will be analysed and discussed with regard to their significance for understanding key developments in rural development policy and practise. It will be shown that the way in which support for joint learning and innovation between grassroots development initiatives and facilitating agents and agencies is arranged differs considerably between the case study areas. Some case study areas seem to be more advanced in effectuating collaborative modes of governance than others. Differences in collaborative modes of governance can arguably be ascribed, at least in part, to the different historical 
political dynamics, their different economic and demographic situations, as well as an explicit, shared sense of place. To raise collective agency thus encompasses a joint reconsideration and redefinition of the division of roles and tasks, including those of public administration. This can be supported by facilitating joint reflexivity among development actors and giving room for collaborative leadership and operational flexibility within policy arrangements.

\section{The learning rural area framework}

Public policy can support the raising of collective agency by facilitating interfaces through which various actors jointly learn and innovate. This has been extensively studied and supported with regard to regional development policies (see for example Asheim, 1996; Florida, 1995; Rutten and Boekema, 2007). Within the rural development literature, however, little attention has been given to the way in which public support can facilitate the creation of interfaces through which joint learning and innovation between facilitating agents and agencies and grassroots development initiatives can occur. Instead, research has focused on facilitating learning and innovation within grassroots development initiatives, such as the role of extension services (e.g. Leeuwis, 2004), or the role of LEADER and participatory processes (e.g. Dargan and Shucksmith, 2008; Shortall, 2008; Shucksmith, 2010), or the role of social learning processes (e.g. Ellström, 2010; Fenwick, 2010; Wals, 2007) and the role of knowledge or innovation brokers (Howells, 2006; Klerkx et al., 2009; Klerkx and Leeuwis, 2009; Suvinen et al., 2010). In response to this gap, Wellbrock et al (2012) proposed a research tool, the learning rural area framework, to investigate interfaces through which facilitating agents and agencies and grassroots development initiatives learn to work together in rural areas. 
The rural learning area framework is based on the learning region concept, broadly defined as 'focal points for knowledge creation and learning in the new age of global, knowledge-intensive capitalism [...]. Learning regions function as collectors and repositories of knowledge and ideas, and provide the underlying environment or infrastructure which facilitates the flow of knowledge, ideas and learning' (Florida, 1995, p. 527). Within regional development, the learning region concept has extensively been used to study and formulate public policy aimed at supporting joint learning and innovation between academia and industry in order to facilitate the production and transfer of new, scientific knowledge and human capital within high-tech, science, media, and communication and information industries in urban, economic centres (Woods, 2009). Public policy can facilitate the creation of learning regions by ensuring spatial proximity between knowledge institutes and businesses in form of so-called economic knowledge 'clusters' (Asheim, 1996; Etzkowitz and Leydesdorff, 2000; Florida, 1995; Morgan, 1997; Rutten and Boekema, 2007; Storper, 1993; Wolfe, 2002).

The current focus of the learning region concept on business-academia-government linkages, also referred to as triple helix (Etzkowitz, 2003), does not, however, serve to study the support for joint learning and innovation in rural areas (Dargan and Shucksmith, 2008; Shucksmith, 2009; Terluin, 2003; Wellbrock et al., In Press; Wellbrock et al., 2012). In contrast to economic knowledge clusters in industry, rural areas are characterised by a high diversity of actors and activities contributing to the development of an area (Roep et al., 2009). Consequently, unlike in economic knowledge clusters, the support for joint learning and innovation required in rural areas is highly context-dependent and problem-specific (Tovey, 2008). Wellbrock et al (2012) thus broadened the scope of the learning region concept to account for the diversity of actors and activities which jointly contribute to the development of a rural area. This amendment reflects a realisation that development in terms 
of economic success, particularly under globalising conditions, cannot be achieved by only focusing on economic issues. It is also part of non-economic social, cultural and institutional dimensions operating at more local and regional levels (Jones, 2001; MacLeod and Goodwin, 1999). It also entails a focus on how dynamics unfold in a particular place (Lyson, 2006; Marini and Mooney, 2006; Woods, 2007).

As illustrated in Figure 1, the learning rural area framework includes the pillar rural area comprised of various assets, activities and actors in which 'grassroots development initiatives' are employed by residents of a rural area. Grassroots development initiatives are defined as development activities initiated in response to pressures on the livelihoods of rural residents (Smith et al.). Rural areas can coincide with administrative boundaries but not necessarily. Instead these places distinguish themselves by a particular political history, culture, identity, natural resources and socio-economic development reflected in the landscape. A further pillar of the framework is the knowledge support structure, including 'facilitating agents and agencies' which jointly learn and innovation together with grassroots development initiatives. These can include public and private knowledge institutes, private consultancy services, public officers, public institutes, NGOs as well as experts involved in education, research and consultancy. Finally, the framework includes the pillar public administration, involved in the formulation and implementation of public policies. Some public policies specifically aim at supporting joint learning and innovation among facilitating agents and agencies and grassroots development initiatives (e.g. LEADER); others aim at attuning research, education and advice to the needs of rural development.

\section{Insert figure 1 here}

Figure 1. Framework for an integrated perspective on learning rural areas.

Source: Adapted from Wellbrock et al. (2012) 
Following the learning region concept, the analytical focus of the learning rural area framework is on policy arrangements that facilitate interconnections through which facilitating agents and agencies and grassroots development initiatives learn to work together. These interconnections are referred to as 'operational interfaces', and are defined as critical focal points, enabling people to learn together and from one another, thereby acting as channels for dialogue and cooperation (Nyhan, 2007). Operational interfaces are based on constitutive agreements on how to operationalise the available public support. Constitutive agreements are the result of a negotiated, novel way of 'doing things together' and hence reflect the collective agency that is being built. Constitutive agreements can be made just by public officers or negotiated in partnership with facilitating agents and agencies as well as grassroots development initiators. As Roep et al (2011) have shown, negotiations concern a) the type of development actors that learn to work together (operational agents and agencies), b) their tasks and roles as well as rules and regulations governing their joint learning and innovation and c) the duration of joint learning and innovation. By agreeing on a set of rules for engagement, partners involved reflect on existing, shared codes of conduct and change them accordingly (Wolfe and Gertler, 2002). Governance is thus not just the formal organisations of government; it is also those norms and standards that influence society's formal and informal ways of thinking and acting (Healey, 2004). The process of coming to a constitutive agreement can therefore be referred to as institutional reflexivity (Wolfe and Gertler, 2002). An institutional perspective on governance as advocated in this study stresses the socially constructed nature of the world in which individuals may be constrained by structure, but where choice can also be exercised (Giddens, 1984; Healey, 2006a; Murray and Murtagh, 2004). Naturally, operational interfaces might therefore also be subject to conflicting values and interests as well as different levels of power (Long, 1984). Gonzáles 
and Healey (2005) draw attention to the shifting emphasis towards governance, and the need to create the necessary institutional space for all relevant partners to promote innovative actions and to control potentially dominant networks of influence. Arguably, this will lead to institutional reform and the creation of a favourable institutional setting for place-based development. The framework can be used as a tool to evaluate the appropriateness of the existing institutional setting and its arrangements, to help identify institutional voids (Hajer, 2003), and to design new institutional arrangements.

\section{The Six Case Study Areas}

Explorative research was carried out within six European (predominantly) rural areas: County Roscommon in Ireland; Comarca de Verín in Spain; the Western part of Groningen Province in the Netherlands (the Westerkwartier); Saarland (west) and Upper Lusatia-Lower Silesia (east) in Germany and Alytus County in Lithuania (see fig. 2). All case study areas were covered by the European LEADER programme.

\section{Insert figure 2 here}

Figure 2. Case study areas.

Some case study areas coincide with existing administrative units, others can be considered as newly emerging development areas crossing administrative borders. Roscommon County and Saarland coincide with existing administrative units. Alytus County, the Comarca de Verín, Westerkwartier and Upper Lusatia-Lower Silesia are emerging development areas. Emerging development areas have no authoritative or regulatory power. The delegation of decision-making power has to be negotiated at the respective government levels. Their unity is expressed in shared cultural, economic and political development. Alytus 
County $^{1}$ identifies with the ethno-cultural identity of Dzūkija region. A Comarca is a traditional Iberian unit that uses common criteria (territory, agrarian or economic activity) to group neighbouring municipalities. The Westerkwartier consists of four municipalities collaborating as a LEADER region since 2007. Upper Lusatia-Lower Silesia is a cultural area (Kulturraum) that includes the eastern parts of the Free State of Saxony in Germany. It consists of the districts Bautzen and Görlitz which were formed in the context of the latest administrative reform in 2008. Subareas of Upper Lusatia have traditionally been inhabited by Sorbs who still practise their own culture, tradition and language.

Each case study area has its particular dynamics. Table 1 only summarises their main contextual differences. Saarland is the largest case study area $\left(2,568.65 \mathrm{~km}^{2}\right)$ and the Westerkwartier is the smallest $\left(345 \mathrm{~km}^{2}\right)$. The Westerkwartier has, however, the second largest population density (173.4 inhabitants $\left./ \mathrm{km}^{2}\right)$. Upper Lusatia-Lower Silesia, Alytus County and the Comarca de Verín are characterised by a shrinking economy, out-migration and an aging population. In Alytus County, for example, the population density decreased by 3.6\% from January 2010 to January 2011 (Jones et al., 2011). Population growth in County Roscommon was also well below the regional and national average. The Westerkwartier and the Western part of Saarland are attractive residential areas for young families and commuters working in close-by urban centres. Along with Roscommon County, their economies depend increasingly on the service sector and construction businesses, while witnessing a steady decline of primary sector activities, particularly those connected to agriculture.

\section{Insert Table 1 here} ${ }^{1}$ In 2010 , the administrative unit of 'Alytus County' was dissolved. Administrative functions
were handed over to municipalities. 


\section{Research Method}

Empirical research was carried out simultaneously in all case study areas between February 2009 and June 2011(Roep et al., 2011). The learning rural area framework was thereby used as a research tool to guide the investigations along three lines (Wellbrock et al., 2012):

First, the learning rural area framework was used to map supporting policies and programmes and facilitating agents and agencies from the knowledge support structure. To do so, an inventory of public policies and programmes specifically supporting joint learning and innovation was made in each case study area. This was done through extensive literature reviews and semi-structured expert interviews with 10-15 relevant informants from public administration and the knowledge support structure in each case study area.

Secondly, the learning rural area framework was used to map and analyse policy arrangements supporting joint learning and innovation between grassroots development initiatives and facilitating agents and agencies. Policy arrangements were described with regard to their constitutive agreement on a) their operating agents and agencies, b) their delegated tasks and roles and associated rules and regulations, and c) the duration of the operational interface. To do so, an inventory of 10-15 grassroots initiatives was constructed, identified through snowball and internet research as receiving some sort of public support for joint learning and innovation, in each case study area. The initiatives covered diverse fields of development (agriculture, nature and landscape development, civic and community development, and economic activities) and were assessed in relation to their aim, their initiators, the range of actors that were engaged with them and particularly the type of support received and the relevant supporting policy arrangement. The inventory was done by questioning key-actors of the initiatives using semi-structured interviews.

Third, the framework can be used as a tool to facilitate a comparison and evaluation of existing policy arrangements, and in particularly their operational features. For this, up to 
eight promising policy arrangements were selected in each case study area for an in-depth study of their operational interfaces. This involved face-to-face interviews and group discussions with selected key informants from public administration, from the knowledge support structure and from grassroots development initiatives. The focus was on identifying factors contributing to or constraining the achievements of grassroots development initiatives.

\section{Arrangements to raise collective agency in rural areas}

In this section, we focus on comparing promising policy arrangements that were identified by Roep et al. (2011) using the research method and framework as explained in section four. The different policy arrangements are compared with regard to their constitutive agreements on 1) the operating agents and agencies, 2) their delegated tasks and roles, and associated sets of rules and regulations (regimes), and 3) the duration of the operational interface. The core of the analysis is specifically targeted at those features that make operational interfaces work well from the perspective of grassroots development initiatives, knowledge facilitators and public administration, taking into consideration the contextual differences across the case study areas.

\subsection{Operating Agents and Agencies}

Roep et al. (2011) revealed four basic types of operational agents: public-private partnerships, grassroots development initiatives, public officers (including officers from institutes of research, education and advice) and private consultants, defined as self-employed experts or professionals working for a private agency.

\section{Insert Table 2 here}


Most interfaces operated as public-private partnerships, consisting of public officers and grassroots development initiatives. The most obvious examples here are the Local Action Groups (LAGs) which were found in all case study areas. In some countries, like Alytus County, public-private partnerships were still considered a novel means of arranging public support but nevertheless emerging. Here, public administration played a dominant role in setting up development agendas. This reduced the trust of rural residents in the support programme and raised sensitive questions about authority and development visions between rural initiators. Grassroots development initiators expressed, for example, their concern that public administration officials entered the LAG as civic partners, for instance as leaders of development initiatives. The number of representatives from public administration thus increased and as a result, grassroots development initiators felt that the LAG did not represent their interests. In other case study areas, like the Westerkwartier, public-private partnerships were more commonly found. One example is the project 'Brug Toekomst' (Bridge Future, 2003-2008) in the Westerkwartier (see also Derkzen, 2009). In this project, public knowledge institutes and grassroots development initiators partnered to test the cooperation of a university and an institute for vocational education located near the Westerkwartier. The Westerkwartier was chosen as a research area, because one of the lecturers was involved in a nature and landscape management organisation in the Westerkwartier. The project required various grassroots development initiatives and public administration to jointly discuss development plans. The knowledge institutes organised and facilitated their meetings, helped to formulate academic research questions and provided students for carrying out the necessary research tasks. The impact of 'Brug Toekomst' was regarded as a success, because it greatly accelerated place-based development in the Westerkwartier. As a result, the Westerkwartier Initiative Group (WSI) was formed, representing the majority of grassroots development initiatives. It continued to act as a key mediator in networks such as the LAG and provided 
continuity in collaboration between public administration, grassroots development initiatives and facilitating agents and agencies, thereby enhancing trust.

Grassroots development initiatives also acted frequently as operational agents. They would either turn into operational agents by introducing members of public administration and the knowledge support structure into their ranks, or by substituting for public administration in providing support for joint learning and innovation between other grassroots development initiatives and knowledge facilitators. As Table 1 shows, the latter form was particularly important in the case of the Comarca de Verín, where relations with municipalities were considered to be 'ruptured'. Here, public officers changed when political colours of the government changed after any election. To secure votes for the new election phase, decisions regarding development were made by public administration alone, leaving little space for negotiation with grassroots development initiatives. In the context of the LAG, for example, tasks and roles were limited to administrative functions such as arranging payments of funds, and providing advice and consultancy. The change of public officers involved in the operation of the LAG after an election further caused a lack of continuity in development agendas and hampered the establishment of trust between supporters and beneficiaries. In contrast, beneficiaries referred particularly positively to the grassroots development initiative "Centro de Desenvolvemento Rural Portas Abertas" (thereafter Portas Abertas). In 1990, Portas Abertas was initiated by a priest, an active development actor in the area at that time, in order to facilitate social inclusion and development in the Comarca. The initiative was integrated into the national NGO 'Confederación de Centros de Desenvolvemento Rural', receiving funds from public and private organisations. In the first two LEADER periods, the association and the local government followed the same political ideologies and Portas Abertas was chosen to operate public funds available through the LEADER programme. During the LEADER period 2007-2013, however, Portas Abertas and 
the municipalities had different political colours and the association distanced itself from the government in order to avoid problems and political power struggles. Even when the budget was cut, it remained an important operational interface, because of its extensive network including representatives within public administration beyond the Comarca and the knowledge support structure. Portas Abertas was regarded as a gateway to public support from European, national and regional government, while circumventing conflict-prone engagement with local government. It helped initiatives with application processes, provided training and knowledge exchange and set up further operational interfaces to support joint learning and innovation. Another example is the LAG of St. Wendeler Land in Saarland. In 1994, this association started as a grassroots development initiative with an informal association of several interest groups engaged with nature and landscape conservation. In 2003, they jointly elaborated a development plan for the area with which they successfully applied for LEADER funds. In 2004, they formalised their collaboration, established the association 'Cultural Landscape Initiative St. Wendeler Land', and were acknowledged as leaders of the Local Action Group Sankt Wendeler Land. Because they were well known in the area, they were perceived as a well-working interface between supporting policies, the knowledge support structure and grassroots development initiatives.

Public officers were the most frequent operational agents in County Roscommon. They were characterised as providing highly professional development support and advice. The Irish Agricultural and Food Development Authority 'Teagasc', a semi-state authority, established in 1988, was for example responsible for learning and innovation in the agri-food sector. In County Roscommon, the authority was represented with three advisory offices. It also had links with universities. It provided a range of support, such as training programmes to assist individuals and grassroots initiatives in innovation and diversification for economic viability. Teagasc's policy remit and funding came via the Department of Agriculture and 
Food. Members of the farming community were also able to take out membership, which entitled them to certain advisory services. Teagasc assisted Local Action Groups with the delivery of training programmes to rural-based communities. Teagasc was valued by its beneficiaries because of its supportive agenda towards rural communities, through having built up long-term connections with them, through listening to their needs and by providing specific advice and supports. Their strong connection to the farming community was a key aspect of this enduring positive relationship. The strong presence of public officers also meant, however, that development strategies were closely tied to policies which continued to be decided at central government level, with little real devolution of decision-making power to lower administrative levels. This created non-negotiable conditions for grassroots development initiatives and constrained supporters who were in favour of more collaborative modes of arranging public support. For example, financial support that flowed from central decisions and criteria did not make any allowances for place-specific demands and deficiencies. Procedural inflexibility and lack of decision-making power at lower levels were seen as main obstacles to an effective arrangement of public support.

Finally, private consultants were also operating as agents. In the Westerkwartier, LEADER funding was used to install 'catalysts' for a period of two years. They stimulated touristic entrepreneurs to envision and carry out joint development plans and to form an association

\subsection{Delegated Tasks and Roles}

Roep et al. (2011) showed that tasks and roles delegated to operational agents and agencies included the provision of the following: financial support (i.e. different kinds of subsidies and procedural support), knowledge and skills (for example advice, facilitation, education and 
research activities), social infrastructure (for example network incubation and cluster forming), and physical infrastructure (for example meeting spaces, information centres).

The provision of financial support was the most frequently-mentioned task. It included the provision of subsidies, support for writing subsidy requests and advice on different kinds of subsidies. Yet, grassroots development initiatives in all case study areas complained about excessively high levels of bureaucracy. The way in which public funds were made available was also not always attuned to the specific needs of an area, as the following examples demonstrate:

Since funds from the LEADER programme were only provided to legal entities, some development activities providing community supports in Alytus County could not be funded. One individual interested in operating a regional internet $\mathrm{TV}$, one producing regional folk costumes for local organisations, and another wishing to establish a foster home could not apply for the available support as private persons, even though their activities supported the community. The formation of legal entities was effectively hampered by the low numbers of residents able to engage in local development, thus acting as a constraint on place-based development in Alytus County.

In the Comarca de Verín, public funds were often oriented towards visible, short-term development goals which would benefit local politicians in the (re-) election phase. The increasing power, clientelism (Hopkins, 2001; Máiz and Losada, 2000) and self-centred interests of local government were argued to jeopardise long-term development visions. In Upper Lusatia-Lower Silesia similar concerns about short-termed political agenda setting and investments were raised. In both areas, public administration arguably showed little reflexivity when allocating public funds, thus constraining a place-based approach to development. 
The provision of skills and knowledge included courses, training, formulating and investigating research questions, providing students to assist with research, and information. In County Roscommon, publically-funded organisations such as Teagasc, FAS (The Industrial Training Authority), the Vocational Educational Committees and the County Enterprise Boards all provided training on a short- or long-term basis to grassroots initiatives. Their support was generally evaluated positively, and also led to long-term relationship between supporters and beneficiaries who in turn helped to create trust. In the Westerkwartier, Saarland, Upper Lusatia, the Comarca de Verín and Alytus County, in contrast, public knowledge institutes providing education, research and advice were engaged with grassroots development initiatives through short-term projects. The practice of involving knowledge institutes was frequently questioned, because the link between development questions of grassroots development initiatives and educational and research programmes appeared to be missing. The service of professional consultants was evaluated positively across the case study areas, but was seen as too expensive to afford on a regular basis.

The provision of social infrastructure, as for example network brokering activities, was referred to in all case study areas. First, network brokers could be rooted, informal, collaborative leaders. This was particularly the case in Saarland, the Westerkwartier and the Comarca de Verín. Collaborative leaders were characterised as having connections with members of public administration and the knowledge support structure. They were also able to motivate others, stimulate joint reflexivity and thus enhancing a joint vision. Examples include the lecturer who introduced the project 'Brug Toekomst' in the Westerkwartier or the priest initiating the association 'Portas Abertas' in the Comarca de Verín.

Secondly, network brokers were experts in certain fields of development activities. For example, in Alytus County there were two business development organisations 'Alytus 
Business Advisory Centre' and ‘Alytus Region Business Association' which became network brokers for other networks and clusters.

Thirdly, to encourage networking activities, informal networking events were organised. In Saarland, these events were organised by public administration. Even though the high involvement of public administration was perceived as a form of constant control, the nearness gave initiatives a high social reputation and support from politically-independent circles. During these events, grassroots development representatives could talk informally with scientists and public officers through whom they could access knowledge, information and other forms of public support. Networks established by public administration tended to persist after initiation. In Upper Lusatia, in contrast, networking events organised by public administration were not welcomed by grassroots development initiatives. They argued that get-togethers with residents who were spread over such a large area as Upper Lusatia did not contribute to the daily work of grassroots development initiatives. Public administration was also perceived as dominating and controlling the operationalization of public support. To save costs, administrative units were constantly enlarged over the last two decades. The enlarged geographical distances resulted in a spatial and cognitive distance between public administration and beneficiaries, and a perceived lack of interest and attention towards development ideas raised by grassroots development initiatives. In addition, the identity of residents and their sense of belonging did not align with the new administrative boundaries.

Fourthly, in County Roscommon and Alytus County, initiators were frequently involved in other initiatives, for example by being members of their Boards of Directors. Along with their official remit, these groupings constituted opportunities to discuss informally with public officers about development policy and funding issues. These networking activities were valued as key for initiatives to focus on their development objectives and operate in an efficient, business-like way. In Saarland networking amongst grassroots development 
initiatives was another important source of support, because the initiatives were often linked to federal umbrella organisations.

Finally, grassroots development initiatives in the Westerkwartier organised networking events themselves using public funds. Examples include the rural cafés which were organised by the foundation 'Westerkwartier Initiative Group'. They were meant to create an informal space for networking, information-exchange and presentations of grassroots development initiatives for citizens, initiators, public administration and knowledge facilitators. Rural cafés were organised twice a year along different themes so that persons with the same interest would be able to meet each other.

The provision of a physical infrastructure refers to the availability of meeting spaces, information centres or office spaces. In the Westerkwartier, for example, an expert team consisting of governmental and non-governmental supporters and associated with the LAG, operated a physical front office called the rural house. This front office housed the different governmental and non-governmental supporters in the area. Being a single access point, it ensured a fast, low-threshold and easy accessible support to beneficiaries. The presence of a physical front office and the instalment of the expert team, mediating between grassroots initiatives and LEADER funding with the decision power to decide on applications for funding up to $€ 10.000$, greatly accelerated the provision of public support. In the Comarca de Verín, a front office was also established. Although it was built to facilitate rural development initiatives, it was used by only two initiatives. This is somehow indicative of the mismatch between political dynamics and development initiatives in Comarca.

\subsection{Duration of an Operational Interface}

The results suggest two types of operational interfaces, long-term commitments to raise collective agency in an area, and short-term 'on the spot' assignments targeted to specific 
tasks. Long-term commitments of public officers or grassroots development initiatives were the most common form of arranging public support for joint learning and innovation. Longterm commitments, for example those of public offices such as Teagasc, FAS (The Industrial Training Authority), the Vocational Educational Committees and the County Enterprise Boards in County Roscommon were valued, because they created continuity and facilitated the formation of trust and partnership. Changes in operators and rules and regulations were regarded as negative for the operation of the support. In County Roscommon, changes in national governments translated into changes in development ideologies, operational agents, programmes, rules and regulations. This often necessitated grassroots development initiatives to reframe their development activities in order to align with the prevailing development ideology, and to invest time and effort in building up relations with new operational agents. This hampered the formation of trust amongst beneficiaries and supporters and presented ongoing practical challenges in terms of formulating applications for financial supports. An example is a local employment support programme. It was regarded as a very important source of support, because it enabled grassroots development initiatives to take on workers and reduce the reliance on voluntary efforts. A recent change in political agenda, however, resulted in a focus on social inclusion which did not allow an initiative to look for staff with specific skills that would have fitted its economic activities. This implied that the initiative had to put time into staff training, which temporarily deflected the focus from development of their core economic strength. Long-term commitments thus also seem to create an element of dependency.

At the same time, short term 'on the spot' assignments were regarded as positive. Short-term assignments were often used as catalysts, for initiating networks or for starting up grassroots development initiatives. The touristic entrepreneurs in the Westerkwartier, for example, helped to envision and carry out joint development plans and to form an association. 
The reason for installing catalysts was the lack of initiative amongst touristic entrepreneurs to form networks and to engage in joint development projects. The primary role of the touristic catalysts was to act as network incubators. They initiated a network of touristic entrepreneurs called the 'touristic platform' by organizing a number of get-togethers open to everyone involved with tourism activities in the Westerkwartier. These initial get-togethers helped connect the different entrepreneurs and to support the realization of their development plans. Eventually, the entrepreneurs recognized the benefits of networking and collaboration and an independently functioning, legal business association was formed. These types of shorttermed assignments were arguably meant to facilitate long-term development.

\section{Towards unfolding more collaborative modes of governance}

The comparative analysis shows that the way in which public support is arranged to raise collective agency differs considerably between the case study areas. Some case study areas seem to be more advanced in effecting collaborative modes of governance than others. In this section, we first discuss factors that arguably contribute to the differences in collaborative modes of governance. Afterwards, the findings will be discussed regarding their significance for understanding rural development policy and practice.

\subsection{Factors influencing the unfolding of more collaborative modes of governance}

Factors which, at least partly, influence the effectuation of more collaborative modes of governance are (historical) political dynamics, economic and demographic situations, as well as an explicit, shared sense of place.

The results indicate that a particular political regime can hamper institutional reform, showing more prevalence for policy-centred modes of governance. In Roscommon County, the central government was, for example, reluctant to cede decision-making authority down to 
lower governmental levels. Accordingly, public support was mainly operated by public officers. The example of Comarca de Verín shows how promising interfaces, such as Puertas Abertas, can be interrupted by a change in political colours of public administration. This indicates the fragility of initial institutional reform. In Comarca de Verín as well as Upper Lusatia-Lower Silesia public administration was also regarded as acting out of self-interest in order to win the next election phase. As Hidle and Normann (2012) suggest, public administration may be accused of abusing their function to realise their own political interests.

Historical political dynamics can also influence the way in which support for joint learning and innovation can best be arranged. Historical political dynamics as for example the forced collaboration and policy-centred modes of governance as experienced in Alytus County seem to be working against a collaborative spirit. Although Alytus County, being part of a transition country and subject to profound institutional reform, is advancing, a more collaborative mode of governance had to be built more or less from scratch. Historically institutionalised centralised power structures thus impact on the prevailing mode of governance (Hidle and Normann, 2012).

Saarland and the Westerkwartier, in contrast, showed more collaborative modes of governance. In these cases, public administration showed well-established practices in delegating decision making power to facilitating agents and agencies as well as grassroots development initiatives. This was reflected in more joint reflexivity, joint capacities, lasting collaborations and tailored arrangements, thus creating a more favourable institutional setting. Arguably, the economic prosperity, net-migration, higher population density and stronger social-cultural ties seemed to favour the effectuation of collaborative modes of governance in the Westerkwartier and Saarland, the two economically most prosperous case study areas. In addition, the political history of Saarland, alternating between French and German territory has resulted in an explicit, shared sense of place and attachment to the area (Wellbrock et al., 
In Press). An explicit, shared sense of place reinforces the willingness and incentives of residents to collaborate (Horlings, 2012). In Saarland and the Westerkwartier, collective agency thus increased as a result of a raised joint reflexivity and a growing collaborative spirit among grassroots initiators and facilitating agents and agencies, engaging in joint development activities. An increased collective agency, in turn, resulted in tailored arrangements to support vibrant collaborations and joint development activities thus providing a more favourable institutional setting.

Shrinking rural economies and related out-migration as experienced in Alytus County and Upper Lusatia-Lower Silesia weaken social relations and vitality by creating 'voids' and posing severe obstacles for initiating a collaborative spirit and uptake of joint development activities. Furthermore, the sense of belonging and attachment to the large scale administrative units like in Upper Lusatia-Lower Silesia explain the apparent reluctance of residents to engage in area-wide, joint development activities. Arguably, public administration has to deal with these unfavourable conditions which hamper the effectuation of more collective modes of governance.

\subsection{Significance for understanding rural development policy and practice}

The analysis suggests that well-working policy arrangements aimed at raising collective agency encompass a joint reconsideration and redefinition of the division of roles and tasks, including those of public administration.

Raising joint reflexivity among residents, facilitating discussions about issues that really matter to them and their place, appears to be a first step towards more collaborative modes of governance. As the cases of Westerkwartier and Saarland show, raising joint reflexivity can be a major incentive to inspire residents, create a collaborative spirit, develop a joint development vision and generate joint activities. In these case study areas visionary 
leaders made the difference. They enjoyed considerable trust and generated inspiring, bounding ideas. They were also capable of bridging diverging interests and transcending (at least temporarily) actual conflicts, and could access additional resources by means of their wider networks. Examples are the members of the Cultural Landscape Initiative Sankt Wendeler Land in Saarland and the founders of the Westerkwartier Initiative Group. These visionary leaders did not operate alone; in fact they enacted collaborative leadership. They initiated and enabled the participation of residents in low threshold meetings, networks, collaborative (private-public) partnerships and wider collaboration in employing development activities. This was also done by the Westerkwartier Initiative Group which organized of rural cafés with LEADER funding to stimulate joint reflexivity. As Gibney (2011) argues, these visionary leaders were well able "to adopt and to mediate the complex interplay of power, resources and people" (p. 618-619). Collaborative leadership thus provides an incentive for joint reflexivity, building collective agency and institutional reform. In Saarland and County Roscommon similar successful networking events were organized by public administration. Yet, such network events do not always succeed as the results in Upper Lusatia-Lower Silesia have shown. Here networking events were organized by public administration and not well perceived by residents, because they lacked a shared identity.

In order to react to the particularities of place, operational flexibility appears to be crucial to the success of a policy arrangement. Yet supportive policies schemes often appear not tailored to the particularities of an area they apply to. Even LEADER procedures, designed to effectuate a collaborative mode of governance with the aim of enhancing collective agency and resilience, can become an obstacle to their own objectives. In the Westerkwartier this has been overcome with advanced, tailored arrangements, such as the touristic catalysts and the expert team to which decision power was delegated. Alytus County, in contrast, had to deal with major political and economic challenges and despite the effort 
made, it was not able to advance that much in effecting collaborative modes of governance. An inherited unfavourable institutional setting can thus be a major obstacle for institutional reform (Kiisel, 2012). A one size fits all approaches do not work. New arrangements have to be tailored to the particularities of a place should they result in effective institutional reform.

\section{Conclusion}

The comparative analysis supports the assumption that the successful implementation of place-based development approaches requires more collaborative modes of governance. The findings also sustain the assumption that collective agency is key to more collaborative modes of governance. Beyond that, the comparative analysis shows that the unfolding of collaborative modes of governance is influenced by favourable political, economic and demographic situations as well as a shared sense of place. The comparative analysis also suggests that more collaborative modes of governance can be effectuated by supporting joint reflexivity among development actors and giving room for collaborative leadership and operational flexibility within policy arrangements. Building on this perspective, the key findings from this research also suggest that understanding the way interfaces between different domains of activities are operationalised and supported in the rural, and how this in turn impacts on the process of joint learning and innovation, provides a more complete picture of the dynamics involved in building collective agency. The analysis also showed the differences with impact of learning collaboratives designed for short- or long- term - intended or unintended. Developing the ideas advanced in particular by Tovey (2008) and Wellbrock et al (2012) about the significance of the rural context, the results suggest a broadening of public policy focus that adopts the learning rural area as a framework for targeting development support that will maximise the likelihood of robust and actually operational interfaces.

\section{Deleted: In}

Deleted: conclusion,This paper commenced by advancing a series of ideas about the effectiveness of collective agency as a means of delivering successful place-based rural development, drawing broadly on contemporary theoretical perspectives that establish the $\begin{aligned} & \text { need for bottom-up initiatives supported by multi-level governance } \\ & \text { structures. ... }\end{aligned}$
.

Deleted: it

Deleted: s

Deleted: sustainable knowledge 
Eventually, this will bring about a negotiated, tailored institutional reform, increasing selfefficacy and resilience as currently advocated in EU-policies.

\section{Acknowledgements}

We would like to thank our fellow DERREG research partners Wioletta Frys, Robert Nadler, Joachim Burdach and project-coordinator Michael Woods for their engagement. We would also like to thank the anonymous reviewers for their helpful comments. We are also grateful to the European Commission for funding the research within the 7th Framework Programme.

This paper is based on research undertaken within WP4 Capacity building, governance and knowledge systems of the project 'Developing Europe's Rural Regions in the Era of Globalisation (DERREG) financed by the 7th Framework Programme of the European Commission. The paper only reflects the views of the authors, and the Commission cannot be held responsible for any use which may be made of the information contained therein.

\section{References}

Amin, A., 2004. Regions Unbound: Towards a New Politics of Place. Geografiska Annaler. Series B, Human Geography 86, 33-44.

Asheim, B., 1996. Industrial districts as 'learning regions': A condition for prosperity. European Planning Studies 4, 379-400.

Barca, F., 2009. Pursuing equity through place-based development policies. Rationale and the equity efficiency issue, OECD/TDPC Symposium on Regional Policy, Paris, France.

Böcher, M., 2008. Regional Governance and Rural Development in Germany: the Implementation of LEADER+. Sociologia Ruralis 48, 372-388.

Bristow, G., 2010. Resilient regions: re-'place'ing regional competitiveness. Cambridge Journal of Regions, Economy and Society 3, 153-167.

Bruckmeier, K., 2000. Leader in Germany and the Discourse of Autonomous Regional Development. Sociologia Ruralis 40, 219-227.

Cleaver, F., 2002. Reinventing Institutions: Bricolage and the Social Embeddedness of Natural Resource Management. The European Journal of Development Research 14, 11-30.

Collinge, C., Gibney, J., 2010. Connecting place, policy and leadership. Policy Studies 31, 379-391.

Dargan, L., Shucksmith, M., 2008. LEADER and Innovation. Sociologia Ruralis 48, 274-291.

Derkzen, P., 2009. Geleerd in het Westerkwartier. Een onderwijsproject in een dynamische regio 2003-2008. Wageningen University, Wageningen.

Ellström, P.-E., 2010. Practice-based innovation: a learning perspective. Journal of Workplace Learning 22, 2740.

Etzkowitz, H., 2003. Innovation in Innovation: The Triple Helix of University-Industry-Government Relations. Social Science Information 42, 293-337.

Etzkowitz, H., Leydesdorff, L., 2000. The Dynamics of Innovation: From National Systems and 'Mode-2' to a triple helix of University-Industry-Government Relations. Research Policy 29, 109-123.

Fenwick, T., 2010. Understanding relations of individual collective learning in work: A review of research. Management Learning 39, 227-243. 
Florida, R., 1995. Towards the learning region. Futures 27, 527-536.

Gibney, J., 2011. Knowledge in a "'Shared and Interdependent World"": Implications for a Progressive Leadership of Cities and Regions. European Planning Studies 19, 613-627.

Giddens, A., 1984. The Constitution of Society. Polity Press, Cambridge.

Gieryn, T.F., 2000. A Space for Place in Sociology. Annual Reviews of Sociology 26, 463-496.

González, S., Healey, P., 2005. A sociological institutional approach to the study of innovation in governance capacity. Urban Studies 42, 2055-2069.

Hadjimichalis, C., Hudson, R., 2006. Networks, regional development and democratic control. International Journal of Urban and Regional Studies 30, 858-872.

Hajer, M., 2003. Policy without polity? Policy analysis and the institutional void. Policy Sciences 36, 175-195.

Healey, P., 2004. Creativity and Urban Governance. Policy Studies 25, 87-102.

Healey, P., 2006a. Collaborative Planning: Shaping Places in Fragmented Societies. Palgrave Macmillan, Basingstoke.

Healey, P., 2006b. Transforming governance: Challenges of institutional adaptation and a new politics of space1. European Planning Studies 14, 299-320.

Healey, P., de Magalhaes, C., Madanipour, A., Pendlebury, J., 2003. Places, identity and local politics: analysing initiatives in deliberative governance, in: Hajer, M., Wagenaar, H. (Eds.), Deliberative policy analysis. Understanding governance in the network society. Cambridge University Press, Cambridge, pp. 60-86.

Hidle, K. Normann R. in the network society. Cambridge University Press, Cambridge, pp. 60-86. Hidle, K., Normann, R.H., 2012. Who Can Govern?
Norwegian City Regions. European Planning Studies, 1-16.

High, C., Nemes, G.v., 2007. Social Learning in LEADER: Exogenous, Endogenous and Hybrid Evaluation in Rural Development. Sociologia Ruralis 47, 103-119.

Hopkins, J., 2001. A 'Southern' model' of electoral mibilisation? Clientelism and electoral politics in post-Franco Spain. West European politics 24, 115-136.

Horlings, I., 2012. Value-oriented leadership in the Netherlands, in: Satorauta, M., Horlings, I., Liddle, J. (Eds.), Leadership and Change in Sustainable Regional Development. Routledge, Oxon, UK, pp. 252-271.

Howells, J., 2006. Intermediation and the role of intermediaries in innovation. Research Policy 35, 715-728.

Jessop, B., 1990. State theory: putting capitalist states in their place. Blackwell, Oxford.

Jones, L., Woods, M., Kairyte, E., 2011. Case Study Contextual Report 9 Alytus County, Developing Europe's Rural Regions in the Era of Globalization, Aberystwyth, UK.

Jones, M., 2001. The rise of the regional state in economic governance: 'partnerships for prosperity' or new scales of state power? Environment and Planning A 33, 1185-1211.

Kiisel, M., 2012. Local Community Participation in the Planning Process: A Case of Bounded Communicative Rationality. European Planning Studies, $1-19$

Klerkx, L., Hall, A., Leeuwis, C., 2009. Strengthening agricultural innovation capacity: are innovation brokers the answer? International Journal of Agricultural Resources, Governance and Ecology 8, 409-438.

Klerkx, L., Leeuwis, C., 2009. Establishment and embedding of innovation brokers at different innovation system levels: Insights from the Dutch agricultural sector. Technological Forecasting and Social Change 76, 849-860.

Lee, J., Arnason, A., Nightingale, A., Shucksmith, M., 2005. Networking: social capital and identities in European rural development. Sociologia Ruralis 45, 269-283.

Leeuwis, C., 2004. Communication for Rural Innovation. Rethinking Agricultural Extension. Blackwell Publishing, Oxford, UK.

Long, N., 1984. A PERSPECTIVE ON THE SOCIOLOGY OF DEVELOPMENT*. Sociologia Ruralis 24, 168-184.

Lowe, P., Murdoch, J., N., W., 1995. Networks in Rural Development: Beyond Exogenous and Endogenous Models, in: Ploeg, J.D.v.d., Dijk, G.v. (Eds.), Beyond modernization: the impact of endogenous rural development. van Gorcum, Assen, The Netherlands, pp. 87-106.

Lyson, T.A., 2006. Global capital and the transformation of rural communities, in: Cloke, P., Marsden, T.K., Mooney, P.H. (Eds.), Hanbook of Rural Studies. Sage, London, pp. 292-303.

MacLeod, G., Goodwin, M., 1999. Reconstructing an urban and regional political economy: on the state, politics, scale and explanation. Political Geography 18.

Máiz, R., Losada, A., 2000. Institutions, policies and nation building: the Galician case. Regional and federal Studies 10, 62-91

Marini, M., Mooney, P.H., 2006. Rural Economies, in: Cloke, P., Marsden, T.K., Mooney, P.H. (Eds.), Handbook of Rural Studies. Sage, London, pp. 91-103.

Marsden, T., Bristow, G., 2000. Progressing Integrated Rural Development: A Framework for Assessing the Integrative Potential of Sectoral Policies. Regional Studies 34, 455-469.

Massey, D., 1991. A Global Sense of Place. Marxism Today, 24-29.

Measham, T., Darbas, T., Williams, R., Taylor, B., 2012. Rethinking rural futures: Qualitative scenarios for reflexive regional development. Rural Society Journal 21.

Morgan, K., 1997. The learning region: institutions, innovations and regional renewal. Regional Studies 31 , Morgan,

Murdoch, J., 2000. Networks - a new paradigm of rural development? Journal of Rural Studies 16, 407-419.

Murray, M., Murtagh, B., 2004. Equity, diversity and interdependence: Reconnecting governance and people through authentic dialogue. Ashgate, Aldershot.

Nienaber, B., 2007. Die Rolle der Landwirtschaft im Konzept der Eigenständigen Regionalentwicklung geographisch untersucht am Beispiel der Region „West” Irlands -. Münstersche Geographische Arbeiten 50. Nyhan, B., 2007. Building learning regions for innovation in Europe: a challenge for education and training, in: Gustavsen, B., Nyhan, B., Ennals, R. (Eds.), Learning together for innovation: promoting learning regions. Office for Official Publications of the European Communities, Luxembourg, pp. 16-34.

O'Brian, K., 2011. Responding to environmental change: A new age for human geography? Progress in Human Geography 35, 542-549. 
OECD, 2006. The New Rural Paradigm: Policies and Governance. OECD Publishing.

Ray, C., 2006. Neo-endogenous development in the EU, in: Cloke, P., Marsden, T.K., Mooney, P.H. (Eds.), Handbook of rural studies. SAGE Publications Ltd., London, UK, pp. 278-291.
Hand

Handbook of rural studies. SAGE Publications Ltd., London, UK, pp. 278-291.
Reimer, B., Markey, S., 2008. Place-based Policy: A Rural Perspective, Canada.

Reimer, B., Markey, S., 2008. Place-based Policy: A Rural Perspective, Canada. Roep, D., Horlings, I., Wielinga, E., 2009. De werkvloer van een Kennisnetwerk Vitaal Platteland. Kennis mak met regionale kennisarrangementen, in: LEI, UR, W. (Eds.). LEI Wageningen UR, Den Haag, the Netherlands. Roep, D., Wellbrock, W., Kairyte, E., Farrell, M., Mahon, M., Frys, W., Nienaber, B., Kriszan, M., Nadler, R.,
Burdack, J., Dominguez Garcia, L., 2011. DERREG D4.4 Summary Report, DERREG Developing Europe's Rural Regions in the Era of Globalisation, Wageningen, The Netherlands.

Rutten, R., Boekema, F., 2007. The Learning Region: Foundations, State of the Art, Future. Edward Elgar Publishing Ltd., Cheltenham, UK.

Shortall, S., 2008. Are rural development programmes socially inclusive? Social inclusion, civic engagement, participation, and social capital: Exploring the differences. Journal of Rural Studies 24, 450-457.

Shortall, S., Shucksmith, M., 2001. Rural development in practice: issues arising in Scotland and Northern Ireland. Community Development Journal 36, 122-133.

Shucksmith, M., 2009. Disintegrated Rural Development? Neo-endogenous Rural Development, Planning and Place-Shaping in Diffused Power Contexts. Sociologia Ruralis 50, 1-14.

Place-Shaping in Diffused Power Contexts. Sociologia Ruralis 50, 1-14. Shucksmith, M., 2010. Disintegrated Rural Development? Neo-endogenous Rural Development, Planning and Mower Contexts. Sociologia Ruralis 50, 1-14.

Smith, A., Fressoli, M., Thomas, H., Grassroots innovation movements: challenges and contributions. Journal of

Storper, M., 1993. Regional "worlds" of production: learning and innovation in the technology distrcts of France, Italy and the USA. Regional Studies 27, 433-455

Suvinen, N., Konttinen, J., Nieminen, M., 2010. How Necessary are Intermediary Organizations in the Commercialization of Research? European Planning Studies 18, 1365 - 1389.

Swanson, L.E., 2001. Rural Policy and Direct Local Participation: Democracy, Inclusiveness, Collective Agency, and Locality-Based Policy*. Rural Sociology 66, 1-21.

Taylor, B.M., 2012. Regionalism as resistance: Governance and identity in Western Australia's Wheatbelt. Geoforum 43, 507-517.

Terluin, I.J., 2003. Differences in economic development in rural regions of advanced countries: an overview and critical analysis of theories. Journal of Rural Studies 19, 327-344.

Tomaney, J., 2010. Place-based approaches to regional development: Global trends and Australian implications. Tomaney, J., 2010. Place-based approaches to regionastralian Business Association, Sydney, Australia.

Australian Business Association, Sydney, Australia.
Tovey, H., 2008. Introduction: Rural Sustainable Development in the Knowledge Society Era. Sociologia Ruralis Tovey, H., 2008 . $185-199$.

Wals, A.E.J., 2007. Social learning towards a sustainable world. Principles, perspectives and praxis. Wageningen Academic Press, Wageningen.

Wellbrock, W., Nienaber, B., Kriszan, M., Nadler, R., Roep, D., Frys, W., In Press. Arranging support of collective learning and innovation in German rural regions, in: Tamasy, C., Revilla Diez, J. (Eds.), Regional Resilience, Economy and Society. Ashgate, Surrey.

Wellbrock, W., Roep, D., Wiskerke, J.S.C., 2012. An integrated perspective on rural regional learning. European Countryside $4,1-16$

Wolfe, D.A., 2002. Social capital and cluster development in learning regions, in: Holbrook, J.A., Wolfe, D.A. (Eds.), Knowledge, Clusters and Learning Regions. Queens University, Kingston.

Wolfe, D.A., Gertler, M.S., 2002. Innovation and Social Learning: An Introduction, in: Gertler, M.S., Wolfe, D.A. (Eds.), Innovation and social learning: Institutional adaptation in an era of technolgical change. Palgrave Macmillan, New York, pp. 1-24. Macmillan, New York, pp. 1-24.

Woods, M., 2007. Engaging the global countryside: globalization, hybridity and the reconstitution of rural place. Progress in Human Geography 31, 485-507.

Woods, M., 2009. Literature Review and Conceptual Framework. Synthesis and Contextualisation of Research and Development of an Interpretative Model, in: Woods, M. (Ed.), Developing Europe's Rural Regions in the Era of Globalisation (DERREG). Aberystwyth University, Aberystwyth, UK. 